\title{
Applying Agile Learning to Teaching English for Specific Purposes
}

\author{
Liudmyla Lazorenko and Oksana Krasnenko \\ Taras Shevchenko National University of Kyiv, Kyiv, Ukraine \\ https:/ / orcid.org/0000-0002-0067-7471 \\ https://orcid.org/0000-0001-9758-3801
}

\begin{abstract}
The present paper aims to analyse the Agile learning implementation and describe the eduScrum practices in teaching English for Specific Purposes (ESP) at Information Technology and Cybernetics Faculties of Taras Shevchenko National University of Kyiv (Ukraine). Based on a mixed-method research design, our research studied Agile learning both qualitatively, and quantitatively through the use of observation, interviews, pre- and post-tests, and the questionnaire. The experimental focus group research proved the efficiency of applying Agile methods in a project-learning environment to teach Information Technology (IT) students. It showed that Agile learning through eduScrum practices encourages communication, knowledge sharing, critical thinking, creativity, enhances student engagement and the development of a mindset aimed at constant improvement. Planning, processing, presentation making, as well as analysis, and assessment practices were outlined in the ESP eduScrum teaching. They facilitated students to acquire and retain the practical experience and become confident lifelong learners in a modern VUCAworld. The criteria-based assessment resulted in drawing students' attention to the problematic aspects of learning and evaluating their knowledge and skills more reasonably. The proposed eduScrum practices could be applied alternatively into the traditional classroom academic environment due to their productivity.
\end{abstract}

Keywords: English for Specific Purposes; Agile learning; eduScrum practices; criteria-based assessment; IT students

\section{Introduction}

Our modern world is more complex and unpredictable than ever. For its description, even a special acronym VUCA has appeared. It stands for volatility, uncertainty, complexity, and ambiguity, a combination of qualities that, taken together, describes the nature of some difficult situations. Bennis and Nanus (1985) firstly used VUCA in the leadership theory in 1987. The term became frequently used and discussed from 2002. Nowadays, VUCA is in new ideas of strategic leadership that apply in a wide range of organisations, from non-profit 
corporations (Wolf, 2007) to education ones (Gaultier Le Bris, Rouvrais \& Waldeck, 2019; Rucker, 2007).

The situation is continually changing, becoming more uncertain each day. In today's management, projects have more and more practical importance because they flexibly meet the requirements of a changeable labour market. A modern VUCA-world needs some professional features from employees: the ability to be flexible, the openness to new ideas, readiness to cooperate in mutual teamwork. Consequently, soft skills are not less important skills as they are critical for being diligent and prosperous in today's workplace. As a result, students have to study quickly, think critically and creatively: globally in prospects as well as tactically in short iterations, putting into practice possibilities that appear. As for future IT specialists, it's better to supplement their technical skills with strong social and collaboration skills. Language proficiency, communication and listening skills, teamwork, agility, patience, persuasion, time and task management enable them to work more effectively, productively and harmoniously with other people (Lazorenko \& Krasnenko, 2019, p. 282). Applying innovative methods of teaching ESP such as Web-quest, Project method, Flipped and Problem-based learning at Taras Shevchenko National University of Kyiv, we focused on Agile learning methodology that increases collaboration, team productivity, and students' engagement, so that it solves problems responding to challenges of contemporary education. Thus, we conducted the experimental focus group research to prove the efficiency of applying Agile methods in a project-learning environment to teach IT students.

Agile learning takes its origin in the world of technology. IT professionals widely use it in Agile software development. Agility was coined by a small group of software industry leaders in 2001 in the influential "Manifesto for Agile Software Development" (Beck et al., 2001) to describe the flexible nature of software developed in iterative stages. It represents a new algorithm of actions for software engineers because it advocates adaptive planning, evolutionary development, early delivery, continual improvement, and encourages rapid and flexible response to change.

Agile software development involves a dynamic requirements formation and implements them successfully as a result of a continuous interaction of experts from different fields. The majority of its methods aim to minimise risks through transforming software development to a series of short cycles or iterations lasting for a week or two. Each iteration looks like a programme project on a small scale and includes all tasks necessary for a minimum increment as for functionality: planning, analysis of requirements, encoding, testing, and documenting. However, every iteration, as a rule, is insufficient for producing a new version of a product. That's why team members revalue priorities of development.

\section{Agile learning principles}

There are three approaches to Agile learning:

1) Agile in the development of educational products;

2) Agile in individual learning progress; and

3) Agile in pedagogical technology implementation. 
We can introduce Agile learning into the courses both as a content and practical method for students. It includes the idea that learners create content and develop skills alongside teachers in a collaborative but competent environment equipped with technologies. Teachers work closely with students, understand their specific needs, respond to them, and adjust accordingly when those needs change (Razmov \& Anderson, 2006). In the process of learning/teaching, the educators rather have the role of a learning facilitator, supporter, or guide and students play the part of the clients. The increments that introduce new functionality in short cycles (sprints) correspond to the continuous growth of students' skills. As a result, they become more self-directed, team-oriented, as well as individually resilient lifelong learners.

Agile provides a manageable set of proven principles that inform the culture and behaviour of organisations. The latter are mostly interested in high results through simple approaches aimed at solving significant problems in unpredictable environments. Peha (2011), an instructional coach, elaborated a version of the twelve principles as characteristics of agile schools:

1. The highest priority is to satisfy the needs of students through early and continuous delivery of meaningful learning.

2. Changing requirements are even useful in the late stages of the learning process. Changes are necessary for students as well as for teachers.

3. Cycles of meaningful learning should be experienced frequently, from a couple of days to a couple of weeks, with a preference to the shorter timescale.

4. Educational institutions, students, and a teacher should work together daily to make meaningful learning possible for all participants of this process.

5. Motivated professionals should work on an educational project. Giving them the environment and support they need and trust them to get the job done.

6. Face-to-face conversation is the most efficient and effective method of conveying information to and within a team.

7. Meaningful learning is the primary measure of progress.

8. The educational process promotes sustainability. It is of paramount importance to maintain a constant pace indefinitely.

9. Continuous attention to technical excellence and good design enhances adaptability.

10. Simplicity - the art of maximising the amount of work not done - is essential.

11. The best ideas and initiatives emerge from self-organising teams.

12. At regular intervals, teams reflect on how to become more effective, then modify their behaviour accordingly (Peha, 2011, Principles for Principals, para. 2). 
The principles mentioned above motivate students to achieve high results and become active participants of the whole educational process. Furthermore, the regulations could boost constant development and readiness to generate and practice innovative ideas. Thus, the basis of Agile includes three components: the process of continuous learning, people motivation, and qualitative changes. At present, they are the most essential for our educational system.

\section{Scrum and eduScrum framework}

Scrum is the most widely-used framework for agile development. Sutherland (2014), a co-creator of the Agile software development process and a co-writer of the Agile Manifesto, affirms that any organisation in different fields can apply scrum. It explains how to precisely define what it is that you're eager to achieve, how to achieve it, and how to monitor progress until the project is completed (Sutherland, 2014).

Based on "the three pillars: Transparency, Investigation, and Adaptation" (Wijnands \& Stolze, 2019, p. 106), eduScrum has become an educational version of a scrum since 2011. According to Wijnands (2019), its founder and a team member of the worldwide initiative "Agile in Education", the core task to deal with is the development of students' personality. It is believed that teachers should provide learners with opportunities to improve their skills. The focus is not on rigid plans, but flexibility is required to take into account students' feedback and their different abilities, interests, difficulties, and experiences, aiming at unlocking their hidden strengths and passions. The emphasis is on delivering the highest value, in terms of both discipline-specific learning outcomes and soft skills as an organisation, planning, collaboration, and teamwork (ibid).

The main principles of the Scrum framework educational diagram include the following:

1) Think (the teacher defines the product backlog);

2) Design (in each sprint, a subset of the backlog activities is selected);

3) Do (during the sprint, the teams solve the problems of the sprint backlog); and

4) Deliver (a product of sprint, reports of the solutions are delivered) (Dinis-Carvalho, Fernandes \& Filho, 2017; Reston \& Lima, 2018).

In eduScrum, students make assignments on their pace. They plan individual activities and keep track of progress. Teachers, as coaches and inspirational servant leaders determine the "Why" students have to study and the "What" they have to get as a result. The students define the "How" they have to learn and achieve their goals. A team works in a targeted way through a set of tools chosen on purpose. Thus, the students "own" their learning process resulting in intrinsic motivation, fun, personal growth, and better results (Wijnands \& Stolze 2019, p. 96).

The purpose of this paper is to investigate Agile learning implementation, particularly eduScrum practices, in ESP university courses and to prove its efficiency through the experimental study and a criteria-based assessment. Specifically, we aimed to answer the following research questions: 
1. Could Agile learning be implemented in the framework of ESP in the Ukrainian academic settings?

2. To what extent is Agile learning effective in the experimental versus control groups?

3. Which practices does the eduScrum framework in ESP imply?

\section{Literature review}

Originated in the IT field, Agile learning methods were quickly adopted to teaching technology-related courses (E-commerce, Information Systems, Computer Science courses on Programming, Software engineering), as well as the courses on Project Management and General Market Management (Sharp \& Lang, 2018). Today Agile is used as a familiar concept for such practices as Scrum (Schwaber \& Beedle, 2002), eXtreme Programming (XP), Feature-driven development, Lean soft development etc (Cohen, Lindvall \& Costa, 2004). Agile methodologies also include Adaptive Software Development (ASD), Crystal methods, Dynamic Software Development Method (DSDM), and Kanban (Salza, Musmarra \& Ferrucci, 2019).

The relationships between Agile methodologies and Education have given birth to Agile Education that "creates a learning environment favourable for the creation of responsible and sustainable citizens" (López-Alcarria, OlivaresVicente \& Poza-Vilches, 2019, p. 1-2). Consequently, students become prepared for lifelong learning. The acquired skills enable them to learn on their own and self-develop.

At present more and more high educational establishments are implementing Agile as a prospective approach in the academic environment (Andersson \& Bendix, 2006; Chun, 2004; Lang, 2017; Monett, 2013; Pinto Ferreira, Mendonça \& Nicola, 2017; Razmov \& Anderson, 2006; Reston \& Lima, 2018; Vuokko \& Berg, 2007). The Agile framework is well suited both for the classroom environment and individual learning. Peha (2011) affirms that "we in education have much to learn from the world of software development and that Agile gives us a wellreasoned, well-researched methodology from which we derive effective practice" (Peha, 2011, Shall we have a go, then? para. 1). Galés and Galon (2019) regard it as "an opportunity to enter a dynamic mindset where transformation and improvement are the goals. It is a bridge between technique, strategy, and values, and it must be seen as an opening for teachers to reflect, debate, and rethink not only procedures but the purpose of education" (Galés \& Galon, 2019, p. 109).

All educational approaches adapted Agile are based on four crucial values from Manifesto for Agile. They are the following:

1) individuals and interactions over processes and tools;

2) working software over comprehensive documentation;

3) customer collaboration over contract negotiation; and

4) responding to change over following a plan (Beck et al., 2001, p. 1).

The second value is interpreted as "meaningful learning over the measurement of learning" (Peha, 2011, A Manifesto for All Seasons, para. 3). These values are about to become very powerful for effective ESP teaching. 
Computer-based communication plays a crucial role in enhancing IT students' quality learning (Rebenko, Nikolenko \& Rebenko, 2019). We could implement Agile practices through popular applications (for example, Slack, Jira, Trello), collaborative apps (Google Docs, Office 365) for document editing in online learning. Teachers and students successfully use Cloud-based online platforms for videoconferencing (Skype, Zoom, MS Teams, Google Meet Hangouts etc). They lead live discussions, cooperate in teams, prepare joint projects and as a result, develop their decision making and critical thinking skills. Students could share online data using such technologies as "blogging, commenting, instant messaging, wiki and XML RSS" (Chun, 2004, p. 11).

In Chun-hui and Fu's paper (2016), the Agile English teaching methods based on the constructivism theory "solve the long-existing problem of separation between teaching and scientific research in higher special English teaching, speeds up the transformation of the scientific research achievements in the teaching practice" (Chun-hui \& Fu, 2016, p. 319). Unfortunately, their study hardly represents the practical implementation of this methodology.

Jurado-Navas and Munoz-Luna (2017) describe the fruitful application of the scrum methodology into the English Studies course at the University of Málaga. They give three main reasons why a scrum methodology can be considered as an excellent proposal to accomplish a teaching-learning process of high-quality at universities. The researchers admit that it improves the capacity of using knowledge in a disciplined, critical, and creative way. Additionally, it promotes the coexistence in heterogeneous human groups, and develops the ability of thinking, living, and acting with complete autonomy (Jurado-Navas \& MunozLuna, 2017).

Thus, some research on Agile learning methodology within the business and academic environment has been done. Yet, the issue of Agile learning application at the ESP classroom has been hardly studied.

\section{Methods}

Research design

To investigate the efficiency of applying Agile methods in teaching ESP, we employed a mixed-method research design. It involved the study of experimental and control groups' results through the use of pre- and post-tests to obtain quantitative data. The qualitative research method focused on investigating a problem within its real-life context through observation and interviews. It helped describe career situations in project-making when students study circumstances, gain the problem understanding, propose possible solutions, and choose the most appropriate one. To collect qualitative data, we developed a range of assessment criteria to evaluate students' presentations. We verified the theoretical data experimentally collected in the current paper.

The population of the study and participants

A total of 72 participants were involved in the investigation including two Experimental Groups (EG1 - 16 and EG2 - 19 students) and two Control Groups (CG1 - 18 and CG2 - 19 students) from Cybernetics and IT Faculties at Taras Shevchenko National University of Kyiv (Ukraine) in the spring term of 2018- 
2019 academic year. They were the first-year university students who attended the ESP course. All participants were native Ukrainian speakers. Their ages ranged between 17-19 years. To determine participants' initial language level, we tested them at the beginning of studying. To select four groups of students, we took into account their approximately similar English level. They had B1-B2, and none of them had officially studied English in any English-speaking country.

The ESP training course was organised according to the University official curriculum for the first-year students of IT, Computer Science and Cybernetics Faculties. It covered 44 academic hours in the spring term, particularly 26 academic hours of classwork and 18 - of individual work ( 2 ac. h. of in-class ESP and 1-2 ac. h. of individual work weekly). It included three modules: Storage Devices, Basic Software, and Faces of the Internet. All groups learnt ESP through the Infotech textbook (Remacha Esteras, 2008). The experimental groups followed Agile learning through eduScrum practices, while the control groups the traditional teaching training. Thus, the comparison of these models resulted in revealing the benefits of eduScrum practices in the ESP classroom.

Sample

The research groups were selected following the authors' teaching load. Krasnenko and Lazorenko taught ESP in EG1, EG2, CG1, CG2 of IT and Cybernetics Faculties of the Kyiv University. That's why the current study was limited by four groups, where the number of participants varied from 14 to 19 students. All students gave agreement for the participation and data processing. Nobody refused taking part in the experimental focus group research.

Data collection and data analysis tools

In this study, we collected and processed data through observation, interviews, pre- and post-tests, and the questionnaire. Observation aimed to collect data by implementing eduScrum in the classroom environment during the whole experimental study. Group discussions and interviews enabled us to find out more about teamwork. They also helped students organise their work, understand how to collaborate effectively and improve their soft skills. Interviews took place in the middle of the experimental study and before presenting the projects. The students' results of pre- and post-tests were checked, analysed, compared, and revealed in Tables 1-2 (see The experimental research findings). The anonymous questionnaire (Appendix 1) was run at the end of the experimental study to find out the participants' opinions on Agile learning methods. The obtained data proved the validity of the study and the set objectives. Thirty-five students were willing to learn ESP in eduScrum, so they found the Agile learning principles productive.

Data collection procedures

We visualised the data collection procedures in experimental groups (Figure 1). 
1. Instructions: the key ideas of Agile learning and eduScrum practices revealed in classes at the beginning of the experiment

2. Pre-test assessment: teacher evaluates participants' initial language level before project preparation

3. Team distribution : four-five students per a scrum team; team members choose a scrum master

4. Team learning: students discuss tasks to solve and prepare their project; teacher monitors student learning, gives feedback and run interviews

5. Project work presentation: students make their projects; teacher evaluates and analyses them according to projectmaking assessment rubrics

6. Post-test assessment: teacher evaluates final language level of each participant

Validity

In ESP teaching, we apply mainly criteria-based assessment or assessment for learning, that is "the process of seeking and interpreting evidence for use by learners and their teachers to decide where the learners are in their learning, where they need to go and how best to get there" (Broadfoot et al., 2002, p. 2). 
The criteria-based assessment reveals educational problems and facilitates productive feedback between a teacher and a student.

We followed the modern trends in the social and educational development of PISA (Program for International Student Assessment) results. Our methodology applied a range of criteria, project-making assessment rubrics, in particular, to measure students' achievements.

The main assessment criteria are the following:

- grammar structures and professional vocabulary knowledge (knowledge and understanding);

- grammar and professional vocabulary skills in use (communicative competencies);

- mastery of reading and listening comprehension of job-focused material, question-answering, and multiple-choice making (thinking and reconsidering); and

- skills of writing letters and emails, holding conversations on job-focused themes (application).

The focus group experiment proved the efficiency of the implementation of Agile methods in ESP as well as the benefits of using criteria-based assessment. To demonstrate the external validity of the research results, we applied the Mann-Whitney U-test (Laake, Fagerland, 2015).

\section{Results and Discussion}

\subsection{The experimental research findings}

The experimental research was conducted to prove the effectiveness of Agile learning implementation within an IT student audience. The theoretical study allowed advancing a hypothesis that ESP would be more productive under Agile principles.

The research included three stages:

1. Pre-test assessment to determine participants' initial language level before the project preparation.

2. An experimental study to prove the efficiency of Agile-based assignment system, and to select a course of iterations for a productive Agile application among IT students.

3. Post-test assessment to evaluate participants' final language level and acquired skills in project-modelling according to the exact structure: planning, requirements' analysis, projecting, testing, documenting (4 ac. h. overall).

The research was vertical and open and conducted in the natural environment; that is, all participants' level was tested at pre- and post-test studies.

Pre-test and post-test assessment results are shown in the tables below (Table 1, 2). 
Table 1: Pre-test assessment results of EG1-2 and CG1-2

\begin{tabular}{|c|c|c|c|c|c|c|c|c|c|}
\hline & \multicolumn{2}{|c|}{ High level } & \multicolumn{2}{|c|}{ Sufficient level } & \multicolumn{2}{|c|}{$\begin{array}{l}\text { Intermediate } \\
\text { level }\end{array}$} & \multicolumn{2}{|c|}{ Low level } & ALR \\
\hline Group & No & $\%$ & No & $\%$ & No & $\%$ & No & $\%$ & \\
\hline EG1 & 3 & 18.8 & 7 & 43.7 & 4 & 25 & 2 & 12.5 & 0.57 \\
\hline EG2 & 4 & 21.1 & 8 & 42.1 & 4 & 21.1 & 3 & 15.7 & 0.61 \\
\hline CG1 & 2 & 11.1 & 10 & 55.6 & 5 & 27.8 & 1 & 5.5 & 0.59 \\
\hline CG2 & 3 & $\begin{array}{l}15.8 \\
\end{array}$ & 9 & 47.4 & 4 & 21.0 & 3 & 15.8 & 0.52 \\
\hline
\end{tabular}

Table 2: Post-test assessment results of EG1-2, CG1-2

\begin{tabular}{|c|c|c|c|c|c|c|c|c|c|c|}
\hline \multirow[b]{2}{*}{ Group } & \multicolumn{2}{|c|}{ High level } & \multicolumn{2}{|c|}{$\begin{array}{l}\text { Sufficient } \\
\text { level }\end{array}$} & \multicolumn{2}{|c|}{$\begin{array}{l}\text { Intermediate } \\
\text { level }\end{array}$} & \multicolumn{2}{|c|}{ Low level } & \multirow[t]{2}{*}{ ALR } & \multirow[t]{2}{*}{ Value } \\
\hline & $\mathrm{No}$ & $\%$ & $\mathrm{No}$ & $\%$ & No & $\%$ & $\mathrm{No}$ & $\%$ & & \\
\hline EG1 & 5 & 31.3 & 9 & 56.2 & 2 & 12.5 & 0 & 0 & 0.75 & 0.18 \\
\hline EG2 & 5 & 26.3 & 10 & 52.6 & 3 & 15.8 & 1 & 5.3 & 0.82 & 0.21 \\
\hline CG1 & 2 & 11.1 & 10 & 55.6 & 6 & 33.3 & 0 & 0 & 0.64 & 0.05 \\
\hline CG2 & 3 & 15.8 & 10 & 52.6 & 3 & 15.8 & 3 & 15.8 & 0.61 & 0.09 \\
\hline
\end{tabular}

Calculating ALR, the average learning rate, we applied the formula $k=n / 100$ where $n$ is the points the students got (max - 100). We used the Mann-Whitney U-test to prove the research results' validity.

As it is shown in Table 2, the value has become 0.18 and 0.21 in EG1 and EG2 correspondingly, and 0.05 and 0.09 in CG1 and CG2 correspondingly. These values prove the effectiveness of the Agile learning application (post-test study is nearly three times as much as in Experimental groups than Control ones).

The post-test results proved our success in the hard skills formation of $2 / 3$ of all participants. Students developed general and professional skills, particularly in eduScrum iterations. Additionally, the participants strengthened their soft skills as well as motivation to self-development and applicability to the modern labour market's requirements.

\section{2. eduScrum practices}

In the ESP classroom, we applied a set of eduScrum practices as shown in Figure 2. 


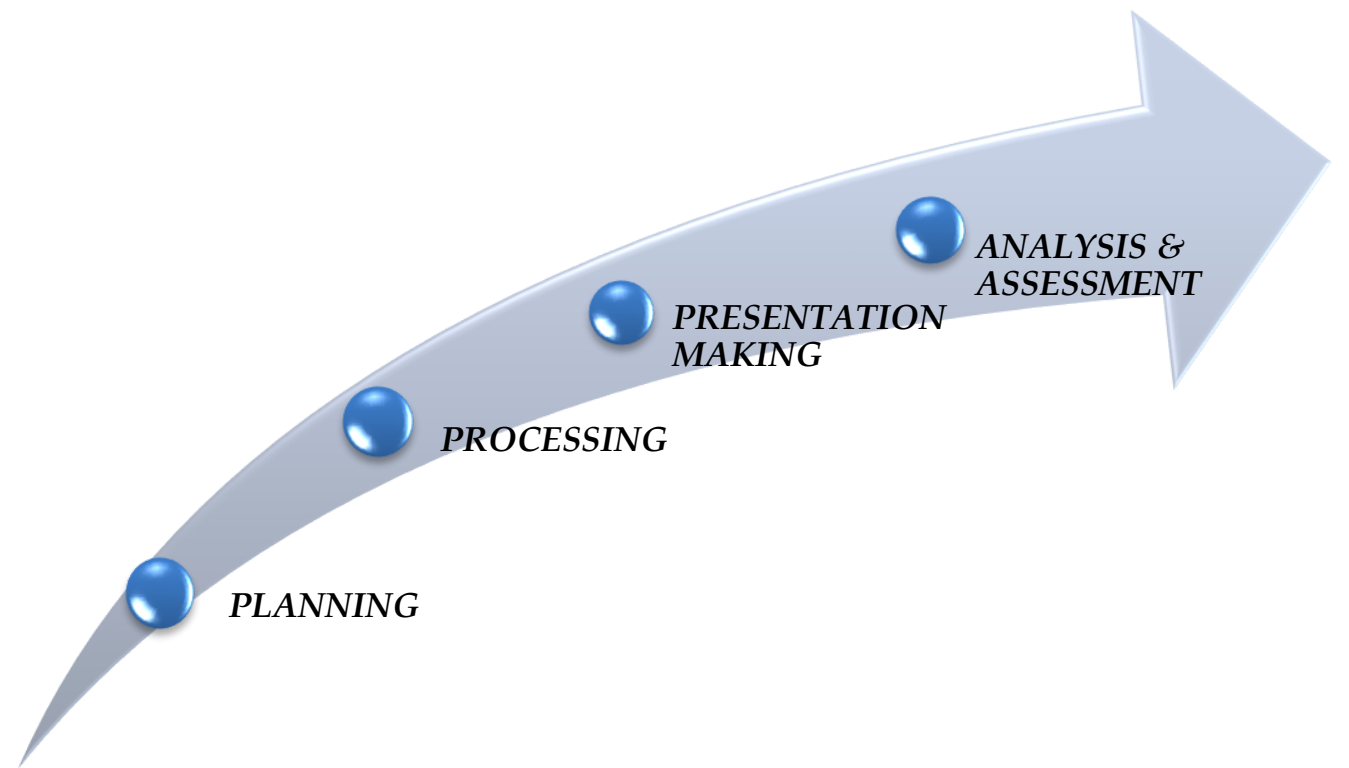

Figure 2: eduScrum practices framework in ESP

Planning. We divided our students into groups (scrum teams) of four-five taking into account students' preferences. The whole training process involved themes, modules. The time for completing each task was equal.

Every student had to identify himself or herself and his/her skills within the team. The team participants managed to organise themselves, understand possible difficulties, distribute the tasks equally, and take over their roles in each group.

eduScrum practices included three roles: the product owner is the teacher who knows the outcome of every scrum team; the scrum master is the student who guides each team; team members are the rest of the participants in each team, including the scrum master (Jurado-Navas \& Munoz-Luna, 2017; Pinto Ferreira et al., 2017; Salza et al., 2019).

Processing. Agile learning includes standups, sprints, and scrums. In a standup, scrum team members organise their future work, answering three critical questions of Graphic Organiser (Appendix 2).

Tasks were grouped into sprints (themes) as the parts of a scrum (a module). Within the sprint, the participants got involved in relevant to ESP problemsolving practices, and then they had to deliver the training outcome. Each sprint ended in students' reflection on the completed assignments, the project analysis, and future activities planning (so-called sprint retrospective).

The first-year IT students had three scrums in the spring term of 2018-2019 academic year represented in Table 3: 
Table 3: Scrums and sprints

\begin{tabular}{|l|l|}
\hline \multicolumn{1}{|c|}{ Scrums } & \multicolumn{1}{c|}{ Sprints } \\
\hline Scrum 1. Storage Devices & Magnetic storage \\
\cline { 2 - 2 } & Optical storage \\
\cline { 2 - 2 } & Flash memory \\
\hline \multirow{5}{*}{ Scrum 2. Basic Software } & The operating system (OS) \\
\cline { 2 - 2 } & Word processing (WP) \\
\cline { 2 - 2 } & Spreadsheets and databases \\
\hline Scrum 3. Faces of the Internet & The Internet and e-mail \\
\cline { 2 - 2 } & the Web \\
\cline { 2 - 2 } & Chat and conferencing \\
\cline { 2 - 2 } & Internet security \\
\hline
\end{tabular}

Presentation making. The students are supposed to demonstrate the eduScrum project work in different forms (reports, multimedia presentations, posters) at the end of each scrum.

It happened that students were shy about what to say or hesitated about how to start the presentation. To help the learners to become confident, we equipped them with a positive and supportive learning environment, familiar and engaging topics, sufficient time to think, plan and accomplish the tasks, and relevant assessment.

The practised eduScrum activities aimed at handling students' timidity are exemplified in Appendix 3. Such actions will make productive vocabulary and, or grammar revision and communicative skills development, as well as motivate students to learn professional English and interact with each other in the team.

Analysis and Assessment. We evaluated the students' presentation making skills and asked them to give feedback on eduScrum practices using the Questionnaire in Appendix 1.

Due to the assessment criteria mentioned in Methods, it was more useful to draw students' attention to the linguistic problems and facilitate them to understand their gaps much clearer.

For instance, below there is a criteria-based assessment scheme on the sprint "Internet Security", the part "The History of Hacking" (Infotech, Module 5, Unit 19), grammar section The Past Simple. The students' task was to prepare and present a project on the history of hacking. Table 4 demonstrates the rubrics of evaluating project-making skills. 
Table 4: Project-making assessment rubrics

\begin{tabular}{|l|l|}
\hline Scoring & \multicolumn{1}{|c|}{ Description } \\
\hline $0-60$ & $\begin{array}{l}\text { Students manifest insufficient knowledge of grammar and } \\
\text { vocabulary on the history of hacking. They miss essential } \\
\text { information which leads to distortion of all content. Students do } \\
\text { not show the system and expediency of using non-verbal units. } \\
\text { Key ideas are difficult to comprehend due to a tiny font, unclear } \\
\text { pictures, and the lack or excess of text messages. Speakers do not } \\
\text { disclose the project essence and do not use the required grammar } \\
\text { structures (more than ten mistakes). }\end{array}$ \\
\hline $61-74$ & $\begin{array}{l}\text { Students manifest satisfying knowledge and understanding of the } \\
\text { thematic vocabulary and grammar structures. Although the lack } \\
\text { of some content-related information distorts the overall idea, the } \\
\text { key message is clear. Non-verbal communication (tables, graphs } \\
\text { etc) is poorly or excessively represented. Text messages are also } \\
\text { numerous. Students render the project idea in a vague manner (5- } \\
\text { 7 mistakes). }\end{array}$ \\
\hline $75-89$ & $\begin{array}{l}\text { Students manifest good knowledge and understanding of both } \\
\text { the professional vocabulary on the theme and the grammar } \\
\text { structures. Although they a few content-related units, the key } \\
\text { idea is not significantly distorted. Students demonstrate without } \\
\text { the content slides. Some non-verbal information is either not } \\
\text { always used or represented excessively. There are some errors in } \\
\text { information representation (for instance, the lack of underlined } \\
\text { font, imprecise graphics, or too-long text messages. Students } \\
\text { render the project idea comprehensively despite few grammar } \\
\text { mistakes (3-4). }\end{array}$ \\
\hline $90-100$ & $\begin{array}{l}\text { Students manifest excellent knowledge of both the professional } \\
\text { vocabulary on the given theme and the grammar structures. They } \\
\text { reveal all the essential and necessary facts in the presentation. } \\
\text { Students apply relevant non-verbal means with the proper links } \\
\text { and visualise the material graphically. Their presentation is easily } \\
\text { perceived, interactive, well-prepared with appropriate font size, } \\
\text { colour emphasis, reasonable use of text messages. Students render } \\
\text { the project idea comprehensively with 1-2 lexical or grammar } \\
\text { mistakes. }\end{array}$ \\
\hline
\end{tabular}

The project assessment criteria included the following standards:

- complete disclosure of received information;

- data compression and representation in the project;

- the reasonable use of non-verbal communication;

- logical data representation; and

- esthetic design of the presentation (Lazorenko, 2016).

Supporting Sadler's ideas on criteria-based assessment (Sadler, 2005), the students became aware of their project work assessment criteria before working in eduScrum. Such a criteria-based Agile learning approach makes the process of assessment more transparent and understandable for students. 
Our investigation showed that eduScrum practices had many benefits in the ESP classroom:

- they created more opportunities for students to think creatively and critically in a self-regulated environment as they had to prepare a joint project in teams;

- helped build social skills and social esteem as students appreciated and accepted the perspectives and world views of their teammates when interacting;

- fostered stronger in-class relationships and a positive learning environment;

- made learning memorable as students were able to apply their knowledge in real-life situations; and

- made students motivated, more attentive, and willing to participate as they understood their contribution to the general result and felt responsible for a team.

We reckon that Agile learning is worthy of attention and requires a lot of planning, many explanations, as well as a significant amount of one-on-one student support. Learners and teachers need some time to get used to this process.

\section{Conclusions}

The English-speaking educational space is one of the most dynamic in terms of the development, the borders' and boundaries' expansion, and the potential of our civilisation. It is an ambitious goal for educators to improve ESP teaching in academic settings and create an efficient modern language didactic model. Agile learning is a promising approach for ESP project-making as it involves the methods that contribute to the rapid and high-quality development of English professionally-oriented speech production. It emphasises the continuity of the learning process, goal orientation, seeking students' feedback, and flexibility in responding to their needs.

We were the first to implement and evaluate Agile learning in the Ukrainian tertiary education, mainly to teach ESP at Cybernetics and IT Faculties of Taras Shevchenko National University of Kyiv. Following Research Question 1, we concluded that Agile learning could be implemented successfully in the ESP learning of IT students. In Research Question 2, we measured the progress the students made. The obtained data showed that there was a tendency for the improvement of the project-making skills of the students from experimental groups. The applied Agile learning proved to be efficient as the students acquired job-focused language proficiency and the required 21st-century competencies: team collaboration, communication, creativity, problem-solving, and decision-making skills. The investigation of Research Question 3 showed that eduScrum practices including planning, processing, presentation making, analysis, and assessment emphasized the student-centred ESP learning process. As a result, the learners became self-directed, team-oriented, and individually sustainable experts for the future in today's fast-paced and uncertain world. A criteria-based assessment made project-making skills evaluating more open and explicit due to the worked-out rubrics. We consider that the obtained experience 
through Agile learning and eduScrum practices could be productive not only in Ukrainian ESP classrooms but also in other international academic curricula.

\section{Research limitations}

This research was limited by two experimental focus groups that learnt ESP in eduScrum during one term. Future researchers might conduct a quantitative and qualitative study for a more extensive period targeting more students as well as teachers.

\section{References}

Andersson, R., \& Bendix, L. (2006). eXtreme teaching: A framework for continuous improvement. Computer Science Education, 16(3), 175-184. doi:10.1080/08993400600912335.

Beck, K., Beedle, M., Bennekum, A., Cockburn, A., Cunningham, W., Fowler, M., ... Thomas, D. (2001). Manifesto for Agile Software Development. Retrieved from www.agilemanifesto.org

Bennis, W., \& Nanus, B. (1985). Leaders: Strategies for taking charge. New York, NY: Harper \& Row.

Broadfoot, P., Daugherty, R., Gardner, J., Harlen, W., James, M., \& Stobart, G. (2002). Assessment for learning: 10 principles. Research-based principles to guide classroom practice. Assessment for learning. London, UK: Assessment Reform Group. Retrieved from http://www.hkeaa.edu.hk/DocLibrary/SBA/HKDSE/Eng_DVD/doc/Afl_pri nciples.pdf

Chun, A. H. W. (2004). The Agile teaching/learning methodology and its e-learning platform. In W. Liu, Y. Shi, Q. Li (Eds.), Advances in Web-Based Learning - ICWL 2004. Lecture Notes in Computer Science, 3143, (pp. 11-18). Berlin, Germany: Springer-Verlag Heidelberg. doi:10.1007/978-3-540-27859-7_2.

Chun-hui, Z., \& Fu, L. (2016). Research on agile English teaching based on constructivism. US-China Education Review, 6(5), 316-319. doi:10.17265/2161623X/2016.05.006.

Cohen, D., Lindvall, M., \& Costa, P. (2004). An introduction to agile methods. Advances in Computers, 62, 1-66. doi:10.1016/s0065-2458(03)62001-2.

Dinis-Carvalho, J. D., Fernandes, S., \& Filho, J. C. R. (2017). Combining lean teaching and learning with eduScrum. International Journal of Six Sigma and Competitive Advantage, 10 (3-4), 221-235. doi:10.1504/ijssca.2017.086599.

Galés, N. L., \& Gallon, R. (2019). Educational agility. In M. Kowalczuk-Walędziak, A. Korzeniecka-Bondar, W. Danilewicz, \& G. Lauwers (Eds.), Rethinking Teacher Education for the 21st Century. Trends, Challenges and New Directions, (pp. 98-111). Opladen, Berlin \& Toronto, Canada: Verlag Barbara Budrich. doi:10.2307/j.ctvpb3xhh.10.

Gaultier Le Bris, S., Rouvrais, S., \& Waldeck, R. (2019). Learning methodology for VUCA situations. Methods and Interdisciplinarity, 1, 117-148. doi:10.1002/9781119681519.ch6.

Jurado-Navas, A., \& Munoz-Luna, R. (2017). Scrum methodology in higher education: innovation in teaching, learning and assessment. International Journal of HigherEducation, 6(6), 1-18. doi:10.5430/ijhe.v6n6p1.

Laake, P., \& Fagerland, M. W. (2015). Statistical inference. In P. Laake, H.B. Benestad, B.R. Olsen (Eds.), Research in medical and biological sciences: From planning and preparation to grant application and publication (1 ${ }^{\text {st }}$ ed.), (pp. 379-430). Amsterdam, Holland: Academic Press/Elsevier. doi:10.1016/b978-0-12-799943-2.00011-2. 
Lang, G. (2017). Agile Learning: Sprinting through the semester. Information Systems Education Journal, 15(3), 14-21. Retrieved from https://files.eric.ed.gov/fulltext/EJ1140882.pdf

Lazorenko, L. V. (2016). Navchannia anhlomovnoho monolohichnoho movlennia maibutnikh matematykiv z vykorystanniam Veb-kvestu [Learning English monologue speech future mathematicians using Web-Quest]. (PhD thesis). Taras Shevchenko National University of Taras Shevchenko, Kyiv, Ukraine.

Lazorenko, L., \& Krasnenko, O. (2019). The importance of developing $21^{\text {st }}$ century skills for advanced students. In A. Jankovska (Ed.), New Stages of Development of Modern Science in Ukraine and EU Countries: monograph (1 ${ }^{\text {st }}$ ed.), (pp. 249-288). Riga, Latvia: Baltija Publishing. doi: 10.30525/978-9934-588-15-0-13.

López-Alcarria, A., Olivares-Vicente, A., \& Poza-Vilches, F. (2019). A systematic review of the use of agile methodologies in education to foster sustainability competencies. Sustainability, 11(10), 1-29. doi: 10.3390/su11102915.

Monett, D. (2013). Agile project-based teaching and learning. Proceedings of the $11^{\text {th }}$ International Conference in Software Engineering Research and Practice. CSREA Press USA, 377-383. Retrieved from https://www.researchgate.net/publication/257414622_Agile_ProjectBased_Teaching_and_Learning

Peha, S. (2011, June 18). Agile schools: How technology saves education (just not the way we thought it would). InfoQ. Web Magazine. Retrieved from https://www.infoq.com/articles/agile-schools-education/

Pinto Ferreira, E., Mendonça, J., \& Nicola, S. (2017). Eduscrum methodology in mathematical engineering education. INTED2017 Proceedings of $11^{\text {th }}$ International Technology, Education and Development Conference. Valencia, Spain. doi:10.21125/inted.2017.0791.

Razmov, V., \& Anderson, R. (2006). Experiences with agile teaching in project-based courses. Proceedings of the ASEE Annual Conference and Exposition. Chicago, IL. Retrieved from https:// peer.asee.org/1018

Rebenko, M., Nikolenko, O., \& Rebenko, V. (2019). Listening comprehension proficiency development of Information Technology students in ESP classroom. International Journal of Learning, Teaching and Educational Research, 18(11), 245-264. doi:10.26803/ijlter.18.11.15.

Remacha Esteras, S. (2008). Infotech English for computer users (4th ed.). Cambridge, England: Cambridge University Press.

Reston, F. J., \& Lima, R. M. (2018). Application of the eduScrum methodology to a higher education institution in the Amazon. Proceedings of the PAEE/ALE'2018, 10th International Symposium on Project Approaches in Engineering Education (PAEE) and 15th Active Learning in Engineering Education Workshop (ALE), 8, 331-335.

Rucker, J. (2007). Memorisation is no longer key to learning. Converge, 3(2), 32-36. Retrieved

from https://web.archive.org/web/20120227195322/http://media.centerdigitaled.co $\mathrm{m} /$ Converge_Mag/pdfs/issues/CON_June07_lorz_PDF.pdf

Sadler, D. R. (2005). Interpretations of criteria-based assessment and grading in higher education. Assessment \& Evaluation in Higher Education, 30(2), 175-194. doi:10.1080/0260293042000264262.

Salza, P., Musmarra, P., \& Ferrucci, F. (2019). Agile methodologies in education: A review. In D. Parsons, K. MacCallum (Eds.), Agile and Lean Concepts for Teaching and Learning (pp. 25-45). Singapore: Springer. doi:10.1007/978-981-13-2751-3_2.

Schwaber, K., \& Beedle, M. (2002). Agile software development with Scrum. Upper Saddle River, NJ: Prentice-Hall PTR. 
Sharp, J. H., \& Lang, G. (2018). Agile in teaching and learning: Conceptual framework and research agenda. Journal of Information Systems Education, 29(2), 45-52. Retrieved from http://jise.org/Volume29/n2/JISEv29n2p45.pdf

Sutherland, J. (2014). Scrum: the art of doing twice the work in half the time. New York, NY: Crown Publishing Group.

Vuokko, R., \& Berg, P. (2007). Experimenting with eXtreme teaching method - assessing students' and teachers' experiences. The issue in Informing Science and Information Technology, 4, 523-534. doi:10.28945/3133.

Wijnands, W., \& Stolze, A. (2019). Transforming education with eduScrum. In D. Parsons, K. MacCallum (Eds.), Agile and Lean Concepts for Teaching and Learning (pp. 95-114). Singapore: Springer. doi:10.1007/978-981-13-2751-3_5.

Wolf, D. (2007). Prepared and resolved: The strategic agenda for growth, performance and change. Traverse City, MI: DSB Publishing. 


\section{Appendix 1}

\section{Questionnaire}

1. Do you think that Agile learning is an excellent experience to accomplish meaningful learning?

2. Did you like to learn ESP in eduScrum?

3. In your opinion, what are the disadvantages of eduScrum practices?

4. How did you find a criteria-based assessment in Agile learning?

5. Would you like to continue learning ESP in eduScrum? 


\section{Appendix 2}

\section{Graphic Organiser}

Name Student A

Data

Topic: The Software Development Cycle

\begin{tabular}{|c|c|c|}
\hline What did I accomplish before? & $\begin{array}{l}\text { What will I do } \\
\text { today? }\end{array}$ & $\begin{array}{l}\text { How will I deal } \\
\text { with? }\end{array}$ \\
\hline $\begin{array}{l}\text { 1. Worked out the professional } \\
\text { vocabulary ND grammar } \\
\text { structures on the topic The } \\
\text { Software Development Cycle: } \\
\text { https://stackify.com/what-is-sdlc/ } \\
\text { 2. Learned about the History of the } \\
\text { Software Development Life } \\
\text { Cycle: } \\
\text { https://www.techopedia.com/defin } \\
\text { ition/22193/software-development- } \\
\text { life-cycle-sdlc }\end{array}$ & $\begin{array}{l}\text { 1. Select the best } \\
\text { definition of the } \\
\text { words ('RC' or } \\
\text { 'release } \\
\text { candidate', } \\
\text { 'shareware', } \\
\text { 'alpha version', } \\
\text { 'freeware' etc.) } \\
\text { 2. Make a list of } \\
\text { decades of } \\
\text { Software } \\
\text { Development } \\
\text { Methodologies. }\end{array}$ & $\begin{array}{l}\text { Create the } \\
\text { expanded } \\
\text { descriptions of } \\
\text { the traditional } \\
\text { staging (e.g. } \\
\text { Planning, } \\
\text { Design, Build, } \\
\text { Deploy, Test, } \\
\text { Maintenance } \\
\text { and Release. }\end{array}$ \\
\hline
\end{tabular}




\section{Appendix 3}

\section{Assignments to Boost Students' Confidence in Public Speaking:}

A) Role-play exercises: e.g., student A is a customer, and student B is a support specialist. Student A asks about taking out an old hard drive / the power supply / the next step in dismantling the old hard drive.

In this case, it's better to give students: 1) some helpful and useful phrases and structures to make up a conversation. For example, I need help taking out... Disconnect the... What is the next step?

2) Some sample dialogue: help?

Support Specialist: Technology Support, Alex's speaking. How can I

Customer: I have an old hard drive and need help taking it out.

Support Specialist: Okay. Unplug the connection to the power supply first. Then, disconnect the motherboard cable.

Customer: Which one is the third power supply?

Support Specialist: It's the smaller black box in the corner.

Customer: I'm unplugging both. What's next?

Support Specialist: Next, take out the two small screws. They fasten the hard drive to the case.

Customer: I see, and then it slides out. Thanks!

The teachers should give as clear instructions as they can help timid students become more confident.

B) Games and funny activities often make shy students forget about their problem to express themselves:

Word race (students in two teams should write as more words as they can on the topic they study, or they have to write words with a given initial letter on the IT theme);

Truth or lie (students write three sentences about themselves where two statements are factual and one of them is false; then they ask each other to find a lie);

Write a story (every student draws a picture on the board; the group is divided into teams, each of them consists at least of 4-5 people; then each team has to make up a story using pictures);

What should I do? (different commands are written on pieces of paper, and stuck to the students' backs; then they ask each other to find out what they should do. For example, you have to create a Website / to delete a file / to write an e-mail); 
Who am I? (stickers with names of the most remarkable people in the IT-sphere (Ada Lovelace, Charles Babbage, Steve Jobs, Tim Berners-Lee, Bill Gates, James Gosling, Linus Torvalds etc) are stuck on students' foreheads, and they try to guess their name asking different questions);

In Lucky Bingo students are given bingo cards where they have to write a random set of seven words into their grid (for example, on the topic Developing software (access method, application, archive, consultant, back end, drawback etc)). The teacher reads out the definitions of these words in random order, and students must decide if one of these words fits the gap. The winner is a student who crossed all terms on the card). Similarly, they can also learn some jobs. For instance, Computer System Analyst (an IT professional who specialises in analysing, designing and implementing information systems), or Web Developer (a programmer who specialises in, or is specifically engaged in, the development of World Wide Web applications using a client-server model). 